PROBLEMS

OF MANAGEMENT

IN THE $21^{\text {st }}$ CENTURY

Vol. 12, No. 2, 2017

106

\title{
THE EVOLUTION OF RISK MANAGEMENT
} RESEARCH: CHANGES IN KNOWLEDGE MAPS

\author{
Iwona Gorzeń-Mitka \\ Czestochowa University of Technology, Poland \\ E-mail: iwona.mitka@zim.pcz.pl
}

\begin{abstract}
One of the leading trends in modern academic research is risk management. Over the years, the approach to risk management has changed and affected many different areas. This study aims to investigate changes in risk management and trends of risk management in the past 20 years. Risk management related publications from 1990 to 2016 were retrieved from the Web of Science and Scopus databases. VOS viewer software was used to analyse the research trend. Literature growth related to risk management is expanding rapidly. Significantly more publications related to risk management aspects were collected in Scopus, compared to the Web of Science. Since 2005 is to be noted a significantly increasing interest in risk management problems (nearly 5300 publications by year in Scopus database). Risk management problems mainly appearing in publications related to the fields of Medicine and Engineering, Business, Management and Accounting, Economics, Econometrics and Finance, Computer Science and Environmental Science. In Business, Management and Accounting a significant jump in the interest in the issues of risk management was noted in 2011. Recent studies focus on the enterprise risk management, environmental and industry management innovation in strong connection with risk assessment. The enterprise risk management associated with environmental and sustainable perspective may be the newest topics that should be closely followed in risk management research.
\end{abstract}

Keywords: risk management, knowledge maps, network analysis.

\section{Introduction}

The knowledge accumulated over time in the risk management field became more and more complex and multidisciplinary. Problems of risk management are studied from the many variety of research perspective (e.g. social sciences, medicine, computer science). Multidimensional risk management issues cause difficulties in identifying leading trends in research. For example, only in the science of management we can find many different approaches, methods and analysis techniques for the decision making process within risk. The issue of risk management in organizations, although extensively discussed on the international level (Gorzeń-Mitka 2007, 2016; Kim\&Vonortas 2014; Liebenberg\&Hoyt 2003; Seamer, Choi \& Doowon 2012) particularly in business practice. Risk management, especially enterprise risk management (ERM), is an important business trend aimed at ensuring an organized and disciplined approach of an organization to the evaluation and management of risks it encounters (Labarge, 2003). World practice shows that risk management has now become an integral part of business activities undertaken by the company, builds value to the organization, shaping the effectiveness of undertaken actions (Hopkin 2010, Mikes \& Kaplan 2013; Wieczorek-Kosmala 2017). Interest of risk management was largely motivated by the indicated importance of this problem for the creation and subsequent performance of firms (Haviernikova, 2016; Kuběnka \& Slavíček 201; Mesjasz-Lech 2012). Nowadays, some researchers suggest that risk management, especially in ERM context, is the key factor to create competitive advantages (Bertinetti, Cavezzali \& Gardenal 2013; Christiansen 2013; Gorzeń-Mitka 2016; Kraus \& Lehner 2012). 
In recent years, we can observe very intensive development in this area. Assessment of this area, identifying of new trends is possible to realise with the help of bibliometrics. Bibliometrics is defined as the application of statistics and mathematics for the analysis of written publications such as books and journal articles (Dabi, Darrigues, Katsahian, Azoulay, De Antonio \& Lazzati 2016). As indicate Khalil and Gotway Crawford (2015) bibliometrics uses the literature system and literature metrology characteristics as research objects and analyzes the literatures quantitatively and qualitatively. Bibliometrics is a good choice to evaluate the trend in research activity over time.

The aims of this study were to examine the trends of risk management research at the global level using the Web of Science and Scopus since 1990. The temporal distribution of publications related to risk management were measured (in specific intervals of the years), together with the most used keywords, and the areas most commonly chosen. Additionally, it was the use of bibliometric mapping tool to create maps of knowledge developments within risk management research. The result of research was presented in reflecting to coexistence. Results were analysed to better understand the change of trends or identify current directions of developments in risk management research.

\section{Theoretical Background}

The evolution of changes in the perception of risk and approach to risk, that have taken place in our consciousness, is interestingly presented by P.L.Bernstein (1997) in his work entitled "Against the Gods: The Remarkable Story of Risk". He points out, among others, that the modern conception of risk has its source in Indo-Arabic numerical system, with the first significant study of risk conducted in the Renaissance. However, the revolutionary idea that was a dividing line between the modern time and earlier historic periods is the idea of risk control. As P.L.Bernstein (1997) stresses, ability to control risk along with a tendency to take risky undertakings and make far-sighted decisions are the basic elements of the driving force of the economic system.

However, the greatest achievements in risk measurement and control were made in the $20^{\text {th }}$ century. The most significant of them include: the publication of the doctoral thesis by F. Knight in 1921 entitled ,, Risk, Uncertainty and Profit” and the research by J. M. Keynes entitled "A Treatise on Probability". At the basis of the analysis of the first of these works is the fundamental distinction between risk and uncertainty. The latter work stresses the importance of perception and the introduction of issues connected with the Law of large numbers.

Another work that influenced the perception of the problem of risk was the theory of strategic games presented by J. von Neumann in 1926. In this theory he points out, among other things, that some loss results from each strategy aimed at winning, rather than avoiding loss (Bernstein 1997). This statement is revolutionary in the sense that for the first time the probability of loss was recognized and connected with risk management as an integral element. The research by J. von Neumann, conducted in cooperation with O. Morgenstern and published in 1953 in the work entitled „Theory of Games and Economic Behaviour”, included, among others, theses on the nature of risk aversion - an attitude that allows to determine how far an organization is able to go in its decisions that can cause others to make decisions that may have undesirable effects on it.

In the same period (that is in 1952) H. Markowitz published his work entitled ,Portfolio Selection" in „Journal of Finance". The key element of his conception is the strategic role of portfolio diversification and selections of the so called effective portfolios with uncertainty and risk as variances taken into account (Bernstein 1997). The approach to control rate of return and risk presented by $\mathrm{H}$. Markowitz is commonly referred to as optimization in the sense of the mean and variances.

Risk management has been a widely debated topic since the 1950s. The first important study in this area by Modigliani and Miller (1958) indicated that the presence of market imper- 
Iwona GORZEŃ-MITKA. The evolution of risk management research: Changes in knowledge maps

PROBLEMS

OF MANAGEMENT

IN THE $21^{\text {st }}$ CENTURY Vol. 12 , No. 2, 2017

108 minimized. A market imperfection such as underinvestment, asymmetric information or under diversified stakeholders are the reasons why risk management exists. Further crucial observations in the field of risk and uncertainty were made by K. Arrow. He proved that we prefer games where there is almost $100 \%$ probability of sustaining a small loss and minimal chances of obtaining a big benefit rather than those which guarantee a small profit and little chances of sustaining huge losses (Bernstein 1997). According to K.Arrow, a condition of the economic growth is providing the possibility of insurance against the consequences of most events, which would encourage risk-taking in the economic activity conducted.

Among other studies that had a significant influence on perceiving risk and uncertainty it should be named the work of D. Kahneman and A. Tversky (1979) on the so called "theory of perspective" from 1979, which explains how people make decisions in the situation of risk. In the conclusions from their research they stated that people are more afraid of losses than they value profits.

First mentions of risk management can be found in the article published in 1956 in the Harvard Business Review article by R. Gallagher entitled "Risk Management: A New Phase of Cost Control". At the same time, Dr. W. Snider from the University of Pennsylvania suggested that „the professional insurance managers should be risk managers”.

At the beginning, the notion of risk management referred to insurance management (the 1960s in the North America). In Europe, first theories about risk management unrelated to insurance appeared in mid-1970s. In 1980s Swiss bankers started to use the term risk management with reference to market and credit risk. In 1990s Professional calculation of risk started to be related with interest rate and currency swaps. In 1996 risk advisors appeared in Swiss banks. In 1997 the first risk officers, risk managers and risk controllers were appointed (Gorzeń-Mitka 2010).

As indicate Bertinetti, Cavezzali and Gardenal (2013), despite the attention given to risk management in the last seventy years, the financial crisis started in 2007 revealed that the traditional tools used by companies to face risks (like hedging and insuring) and traditional framework to risk management, where individual risk categories are managed separately in risk "silos", have revealed themselves to be inefficient in tackling the increasing economic complexity.

For this reason, academics and practitioners were dedicating efforts in defining and developing new approaches to manage risk, one of them is Enterprise Risk Management (ERM), which allows firms to manage a wide array of risks in an integrated and holistic perspective in a systematically and consistently way. Now among the many approaches to risk, enterprise risk management is the leading concept (Bertinetti, Cavezzali \& Gardenal 2013; Lindberg \& Hoyt 2010; Seamer, Choi \& Doowon 2012). Nowadays research in this area conclude that the process should be anchored in the main strategy of the organization as well as in the strategies of its individual units (Bertinetti, Cavezzali \& Gardenal 2013; Gorzeń-Mitka 2017; WieczorekKosmala 2017). The effectiveness of risk management process in an integrated approach depends on its clear definition and communication to all levels of an organisation and corporate risk taking (Armstrong \& Vashishtha 2012; Sipa, Skibnski \& Gorzeń-Mitka 2016; Verbano \& Venturini 2013). As indicates Faccio (2016), the concept of risk taking is a quality that is repeatedly used to describe entrepreneurship. Its principal factor that separated entrepreneurs from hired employees was the uncertainty and riskiness of self-employment (Gorzen-Mitka 2017; Sipa 201; Skibiński 2017). Additionally, as argued Paligorova (2010), risk taking in an organization and its impact on economic performance are critical issues in strategic management.

Risk management has changed substantially over the past ten years, especially in financial sector (i.e. more detailed and demanding capital, higher standards for risk reporting). The management of nonfinancial risks became more important as the standards for compliance and conduct tightened. Stress testing emerged as a major supervisory tool. Organizations also invested in strengthening their risk cultures. 


\section{Methodology of Research}

The research method used was literature review and quantitative method (the bibliometric analysis). A literature review was made based on a survey of theoretical references in risk management area. Bibliometric analysis identifying the areas of research within the concept of risk management took place in selected stages of research (Figure 1). This analysis focuses on the use of the bibliometric analysis to examine the knowledge structure in risk management area and development of research in this field based in past 20 years by analysis of related publications.

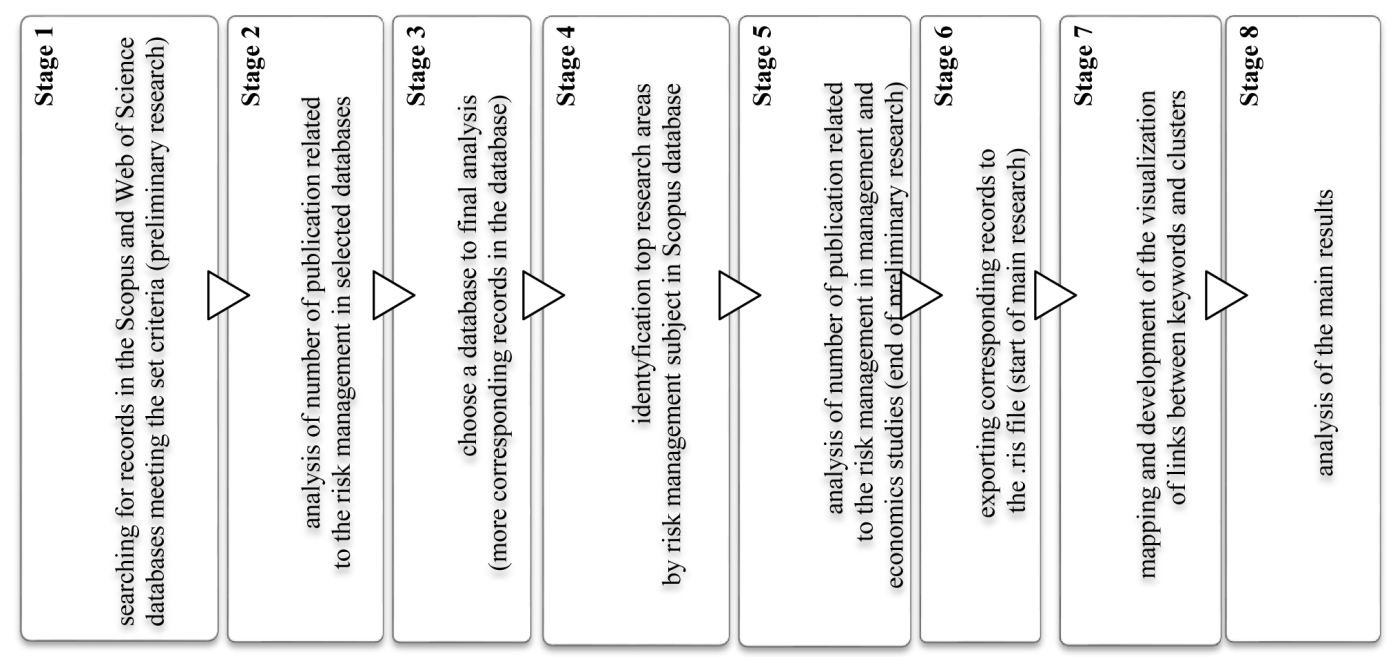

\section{Figure 1: Knowledge maps of risk management - stages of research.}

Source: own elaboration based on Ziegler (2009)

In the first stages of research two databases were used: Web of Science and Scopus to identify research activity on the risk management concept by the number and structure of publications in the period 1990-2016.

To identify the source of changes in the number of publications in Scopus database related to risk management, the investigation of the fields that used the term risk management was made in the 4th stage of research. The analysis was concluded in relation to this criterion which involved number of publications in top 5 subject areas. Most frequently areas (top-5), have been analysed for changes in the number of publications in 1990-2016.

In the 5th stage of research, publications related to risk management in Business, Management and Accounting and Economics, Econometrics and Finance fields, i.e. those, have been analysed for changes in the chain-type indexes in the following years. The goal of this analysis was to show a rate of change and trend line of publication in the subject of risk management.

To identify changes in risk management research, knowledge maps were made, representing the co-existence of issues covered together with risk management over the last 20 years (in 5time interval). The resulting dataset was reduced by choosing only those terms that appeared for at least 20 times and by eliminating expressions characteristic for every publication, such as purpose, trends, theory, and scope. The resulting records database selected from keywords has been ordered and partially aggregated (6th stage of research). Based on them, the VOSviewer tool (VOSviewer software (Visualizing Scientific Landscapes). Version 1.6.5. Developed by the Leiden University Centre for Science base and Technology Studies in the Netherlands) was used to prepare a graphical presentation of frequency and co-occurrence with the rest of the analysed group. Data selection and research procedure using the application 
Iwona GORZEŃ-MITKA. The evolution of risk management research: Changes in knowledge maps

PROBLEMS

OF MANAGEMENT

IN THE $21^{\text {st }}$ CENTURY

Vol. 12, No. 2, 2017

VOSviewer was adapted from study by van Eck and Waltman (2016), Gudanowska (2017) and Olszewska (2017). The analysis of the co-occurrence of keywords was performed with the use of the VOSviewer software van Eck and Waltman (2016).

The 1995-2017 analysis period has been accepted. In order to present changes in the risk management approaches, the selected research period was divided into 5time intervals. Authors' keywords and their co-occurrence were the elements representing the content mentioned in the articles. To present a clear visualization, this paper focuses on those expressions that appeared at least twenty times in a group of selected publications. The analysis disregarded the terms "risk management" and other general interest. The data from selected time intervals was analysed and presented with the use of VOSviewer program. Five maps were created, which visualized changes in trends in risk management studies. For each item, the size of the item's label and the size of the item's circle depend on the weight of the item (in this case - authors' keywords). The distance between items in the visualization approximately indicates the relatedness of them in the co-occurrence network. In general, the closer two items are located to each other, the stronger their relatedness in terms of occurrence links in an analysed group of publications (van Eck and Waltman, 2016).

\section{Results of Research}

\section{Publications in Risk Management Area in 1990-2016}

Research activity on the risk management concept was assessed by the number of publications in two databases: Web of Science and Scopus. The research was focused on publications indexed in selected databases in the period 1990-2016. The breakdown of the number of publications is presented in Figure 2. The number of publications related to the notion "risk management" is different in both databases. Significantly more publications were collected in Scopus, compared to the Web of Science. Looking at Figure 2, it is noticeable that in the Web of Science database for a long period (1990-2005) the number of publications mostly maintained stable at less than about 1000 publications per year. In the same period in the Scopus database the number of publications increased almost threefold. Since 2005 in the Web of Science database, a significantly increasing interest in the aspect is to be noted. Since 2005 in the Scopus database, a significantly increasing interest in the aspect is to be noted, stopping in 2009, at the level of nearly 5300 publications in that year. It was followed by a clear decrease in interest over the year. However, after a few years, in 2013, the number of publications started to increase again, with its peak in the year 2014. The year 2015 came with another minor decrease in the interest in the problem of risk management. 


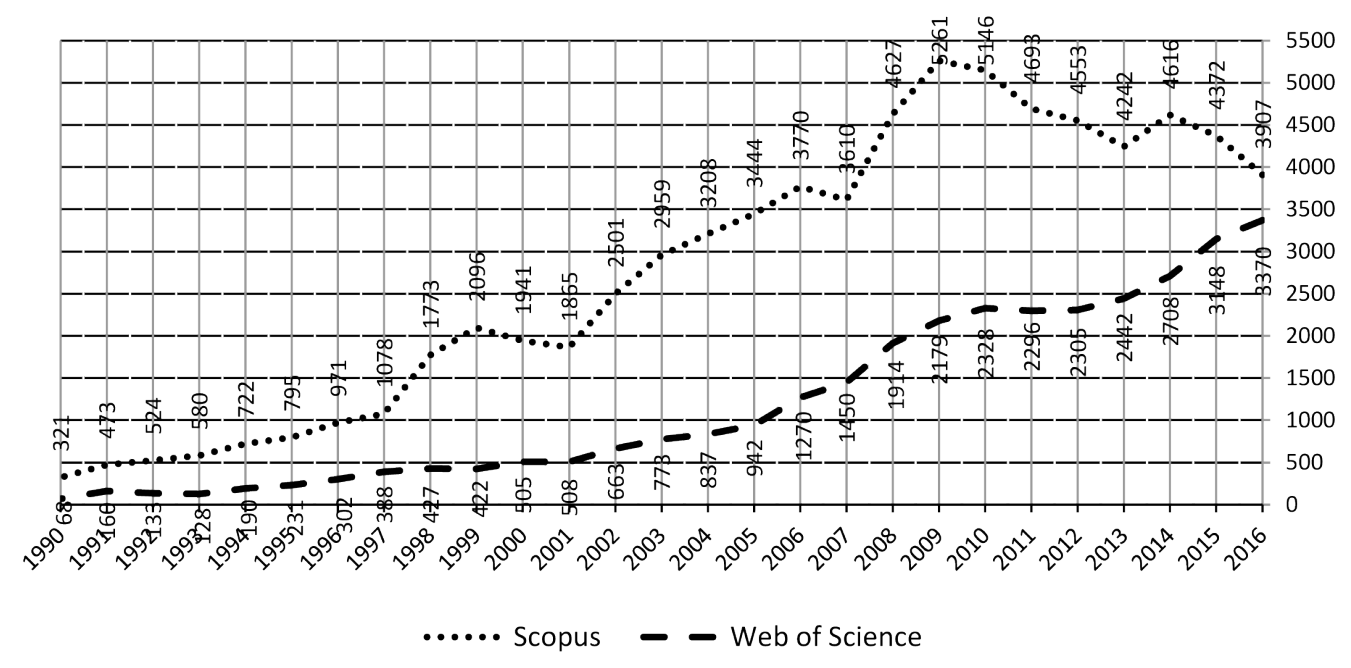

Figure 2: Number of academic literature in risk management area (authors' keyword "risk management" in the Scopus and Web of Science databases in 1990-2016). Source: own processing, data extracted from Scopus and Web of Science databases

That is also why the Author mostly focused on the further considerations, on the data from a more comprehensive database, i.e. Scopus.

\section{Main Research Areas by Risk Management Subject in 1990 - 2016}

In the next step it was analysed a number of publications in top 5 subject areas. Most frequently areas (top-5), have been analysed for changes in the number of publications in 19902016 (Figure 3). Analysing Figure 3, it can be concluded that the term has been mainly appearing in publications related to the fields of Medicine and Engineering. The second areas, in which issues connected with risk management have been described were Business, Management and Accounting, Economics, Econometrics and Finance, Computer Science and Environmental Science. While analysing Figure 3, it is noticeable, that issues related to risk management, described in publications from the fields of Medicine and Engineering indicate the clear upward trend appearing in 1990-2009, which significantly increased in 2009 (Medicine) and 2012 (Engineering). From 2015, the number of publications connected with the described term from the areas of Medicine and Engineering has slightly decreased. The situation looks similar when it comes to the field of Environmental Science. When it comes to the fields of Business, Management and Accounting, Economics, Econometrics and Finance, and Computer Science, a significant jump in the interest in the issues of risk management was noted in 2011. 
PROBLEMS

OF MANAGEMENT IN THE $21^{\text {st }}$ CENTURY Vol. 12, No. 2, 2017

$$
112
$$

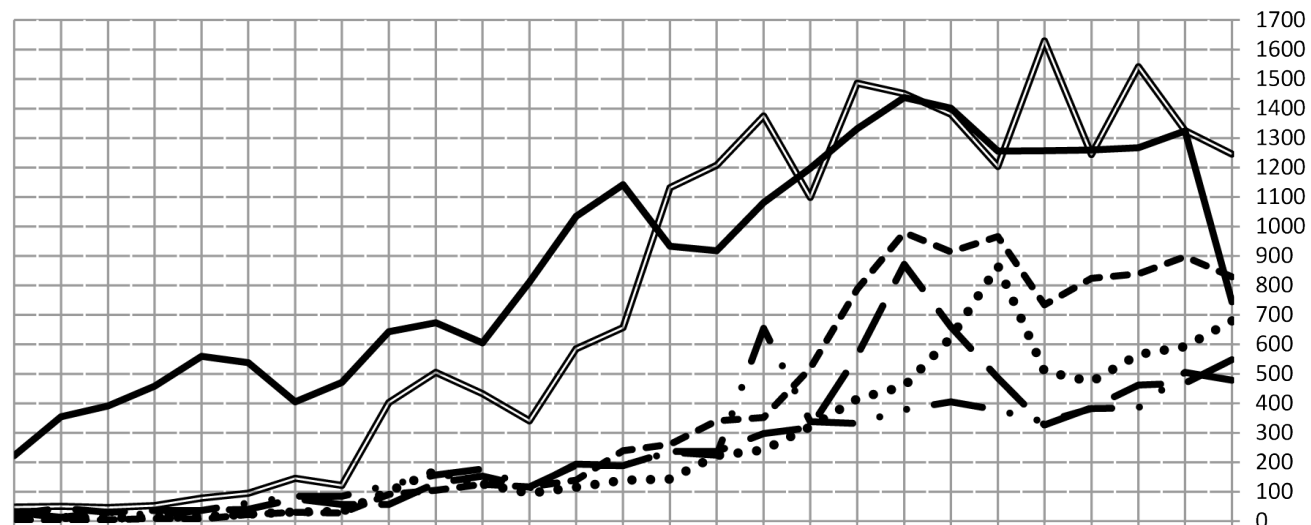

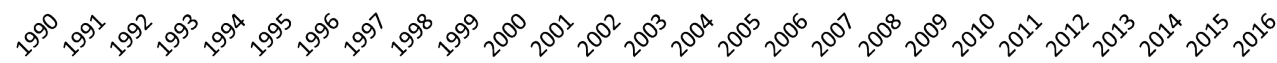

Figure 3: Top 5 research areas by risk management subject (in the Scopus database in the period 1990-2016 [number of publication]). Source: own processing, data extracted from Scopus database

After that, the number of publications decreased sharply (especially in the first field). It should also be noted that the subject of risk management was still increased, despite temporary decreases in areas of Business, Management and Accounting, and Economics, Econometrics and Finance. The medium-term rate of change in 1990-2016 is 24 percent. Changes in $n$ the chain-type indexes were presented in the graph in Figure 4.

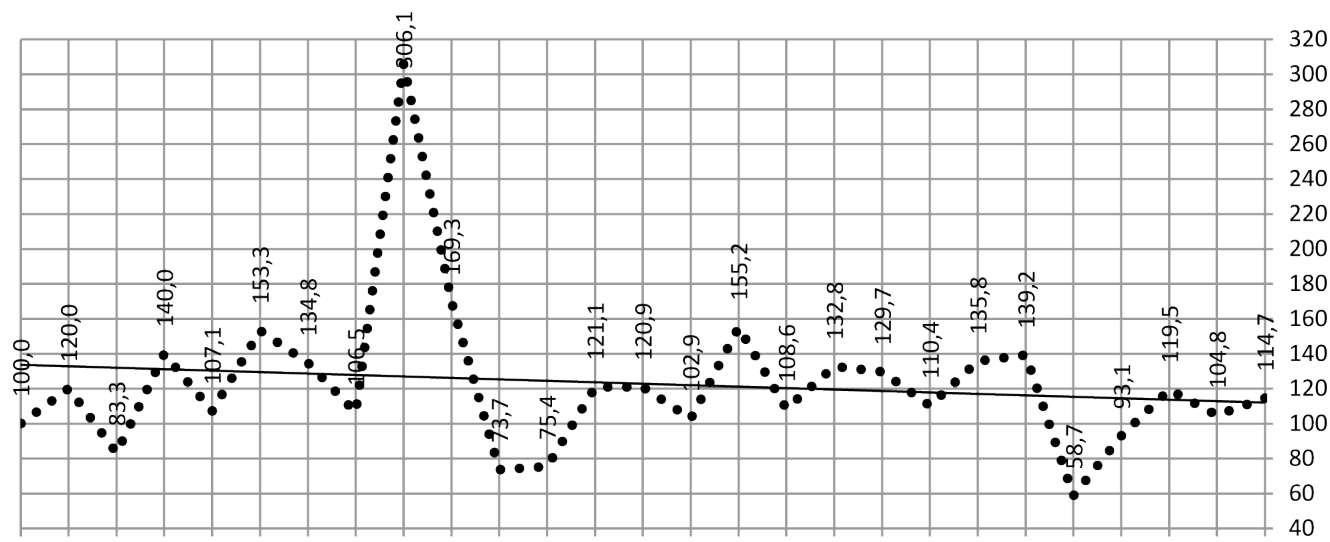

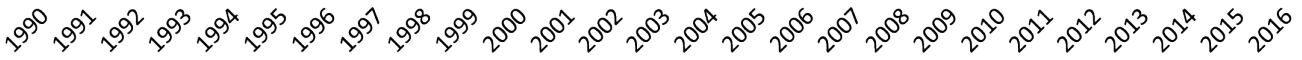

••• Business, Management and Accounting + Economics, Econometrics and Finance

Figure 4: A chain-type indexes and trendline of risk management publication in Business, Management, Accounting and Economics, Econometrics, Finance areas (the Scopus database in the period 1990-2016 [\%]). Source: own processing, data extracted from Scopus database 


\section{A Knowledge Map of Research in Risk Management Area}

To identify changes in risk management research, knowledge maps were made, representing the co-existence of issues covered together with risk management over the last 20 years. In order to present changes in the risk management approaches, the selected research period was divided into 5time intervals. The data from selected time intervals was analysed and presented with the use of VOSviewer program. Maps were created, which visualized changes in trends in risk management studies. For each item, the size of the item's label and the size of the item's circle depend on the weight of the item (in this case - authors' keywords). The distance between items in the visualization approximately indicates the relatedness of them in the co-occurrence network. In general, the closer two items are located to each other, the stronger their relatedness in terms of occurrence links in an analysed group of publications (van Eck and Waltman, 2016). Figures 5-9 present the resulting maps.

Initial map presented in Figure 5 (interval 1995-1999) highlights three primary groups of keywords, which have appeared in publications related to risk management. The map consists of three loosely connected map areas including the most frequently occurring terms. In the central part of the map, which includes most frequently occurring keywords, we can find the terms related to decision theory, strategic planning and industrial economics related to the research and development management. Details on the main keywords and their characteristics by cooccurrences and total links strength related to this map are presented in table 1, in appendix.

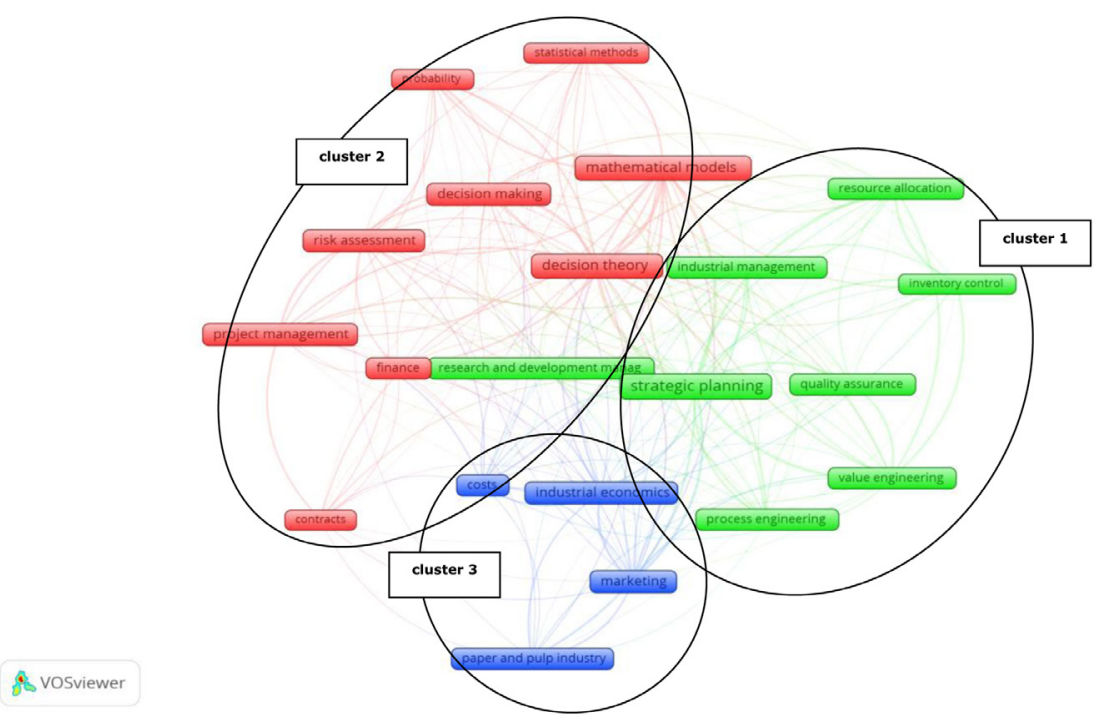

Figure 5: Map of research trends in publications referring to risk management in the period 1995-1999 (based on co-occurrence of the keywords). Source: own processing via VOSviewer program, data extracted from Scopus database.

The first cluster contains terms related to the strategic planning, including, for example, quality assurance, process engineering and industrial management. The second cluster is connected with decision making, decision theory connected to the risk assessment and project management. They are analysed basically with the use of mathematical models and statistical methods. The last third group of publications contains mainly the terms related to the marketing, cost and industrial economics (especially in pulp and paper industry).

Knowledge map presented in Figure 6 (interval 2000-2004) highlights also three primary groups of keywords, which have appeared in publications related to risk management. The map consists of three loosely connected area maps including the most frequently occurring 
PROBLEMS

OF MANAGEMENT IN THE $21^{\text {st }}$ CENTURY Vol. 12, No. 2, 2017

terms. In the central part of the map, which includes most frequently occurring keywords, we can also find the term related to costs, strategic planning, project management related to the decision making and marketing. Details on the main keywords and their characteristics by cooccurrences and total links strength related to this map are presented in table 1, in appendix. The first cluster contains terms related to the decision making analysis basically with the use of mathematical models and statistical methods especially in marketing and finance. Thus, we observe the continuation of the trend recorded in the previous time interval. The second cluster is connected to the project management with strong relation to the risk assessment mostly in public policy context. The last third group of publications contains mainly the terms related to the cost, strategic planning and investment.

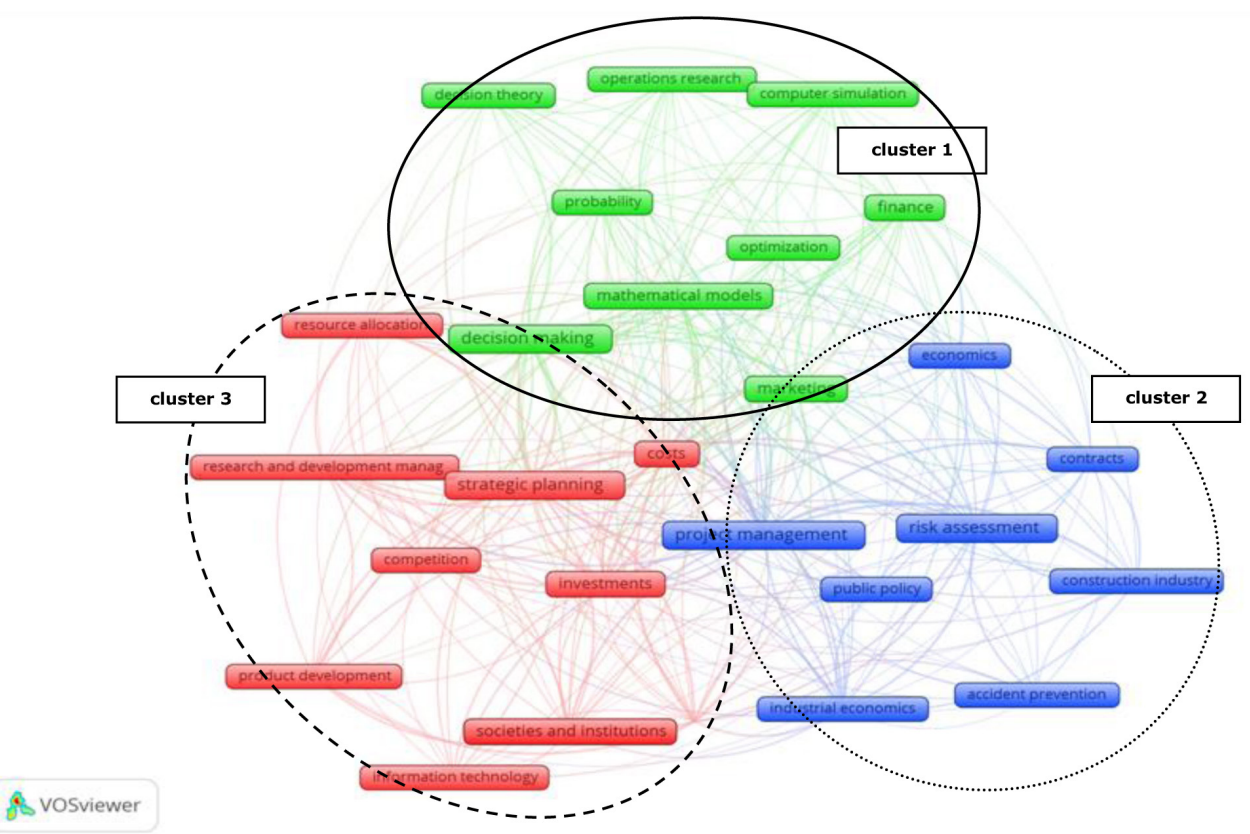

Figure 6: Map of research trends in publications referring to risk management in the period 2000-2004 (based on co-occurrence of the keywords). Source: own processing via VOSviewer program, data extracted from Scopus database.

Knowledge map presented in Figure 7 (interval 2005-2009) highlights five primary groups of keywords, which have appeared in publications related to risk management. The map consists of five strongly connected area maps including the most frequently occurring terms. In the central part of the map, which includes most frequently occurring keywords, we can also find the term related to decision making, risk assessment, strategic planning, disasters and industrial management. Details on the mainly keywords and its characteristics by co-occurrences and total links strength related to this map presented in table 1 in appendix. The first cluster contains terms related to the project management associated with decision making and risk analysis. In this cluster we can find for the first time the term "enterprise risk management". Thus, we observe the continuation and development of the trend recorded in the previous time interval. The second cluster is connected to the separate publications on risk assessment in relation to decision support system, disasters and safety factors. The large third cluster relates to different areas of management like information, knowledge, supply chain in relation to innovation. The next, fourth cluster is connected with different areas of costs perspective in relation to a variety of methods for the analysis. The last fifth group of publications contains mainly the terms related to the strategic planning in public policy context. 


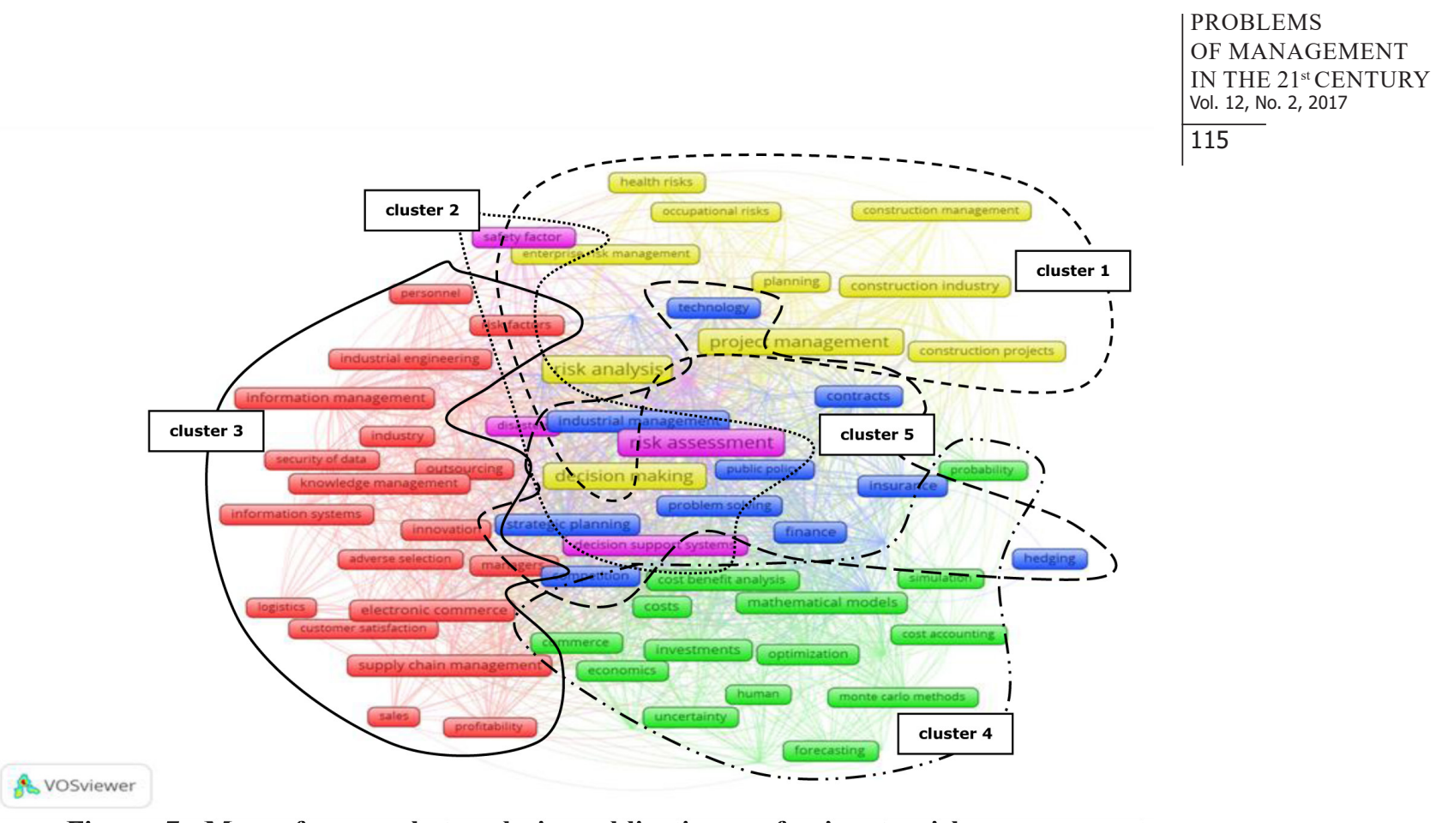

Figure 7: Map of research trends in publications referring to risk management in the period 2005-2009 (based on co-occurrence of the keywords). Source: own processing via VOSviewer program, data extracted from Scopus database.

Knowledge map presented in Figure 8 (interval 2010-2014) highlights six primary groups of keywords, which have appeared in publications related to risk management. The map consists of six even more strongly connected areas maps including the most frequently occurring terms. In the central part of the map we can find new terms related to innovation, security of data, artificial intelligence in connection with industry perspective. Details on the main keywords and their characteristics by co-occurrences and total links strength related to this map are presented in table 1, in appendix. The first large cluster contains terms related to the risk assessment in connection with strong position of enterprise risk management. Thus, we observe the continuation and strong development of the trend recorded in the previous time interval. The second large cluster is connected to the project management in relation to decision making and several aspects of uncertainly. The third cluster is connected with different areas of management like disasters, civil defence in relation to artificial intelligence. The next, fourth cluster is connected with different areas of supply chain management. The last groups of publications contain mainly the terms related to the general context of economics (clusters 5 and 6).

Last knowledge map presented in Figure 9 (interval 2015-2017) highlights five primary groups of keywords. The map consists of five strongly connected areas maps including the most frequently occurring terms. In the central part of the map we can find new terms related to enterprise risk management, environmental and industry management innovation in strong connection with risk assessment. Details on the main keywords and their characteristics by cooccurrences and total links strength related to this map are presented in table 1, in appendix. The first large cluster contains terms related to the enterprise risk management in connection with environmental and sustainable perspective. Thus, we observe the strong development and specialization of the trend recorded in the previous time interval. 
PROBLEMS

OF MANAGEMENT IN THE $21^{\text {st }}$ CENTURY Vol. 12, No. 2, 2017

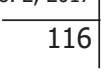

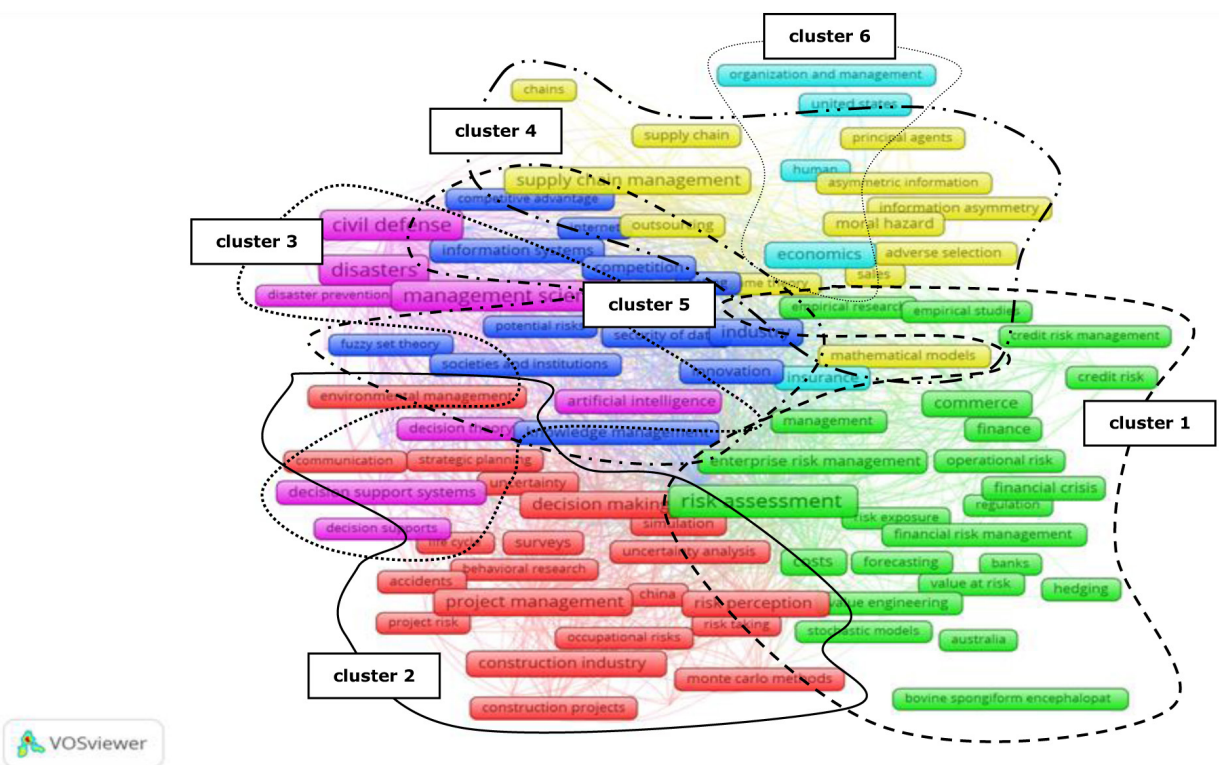

Figure 8. Map of research trends in publications referring to risk management in the period 2010-2014 (based on co-occurrence of the keywords). Source: own processing via VOSviewer program, data extracted from Scopus database.

The second large cluster is connected generally to the commerce aspects. The third cluster contains terms related to the risk assessment, risk analysis and risk perception in connection with project management perspective. Thus, we also observe the strong development and specialization of the trend recorded in the previous time interval. The next, fourth cluster is related to different areas of decision making and emergency management. The last group of publications contains mainly the terms related to the supply chain perspective.

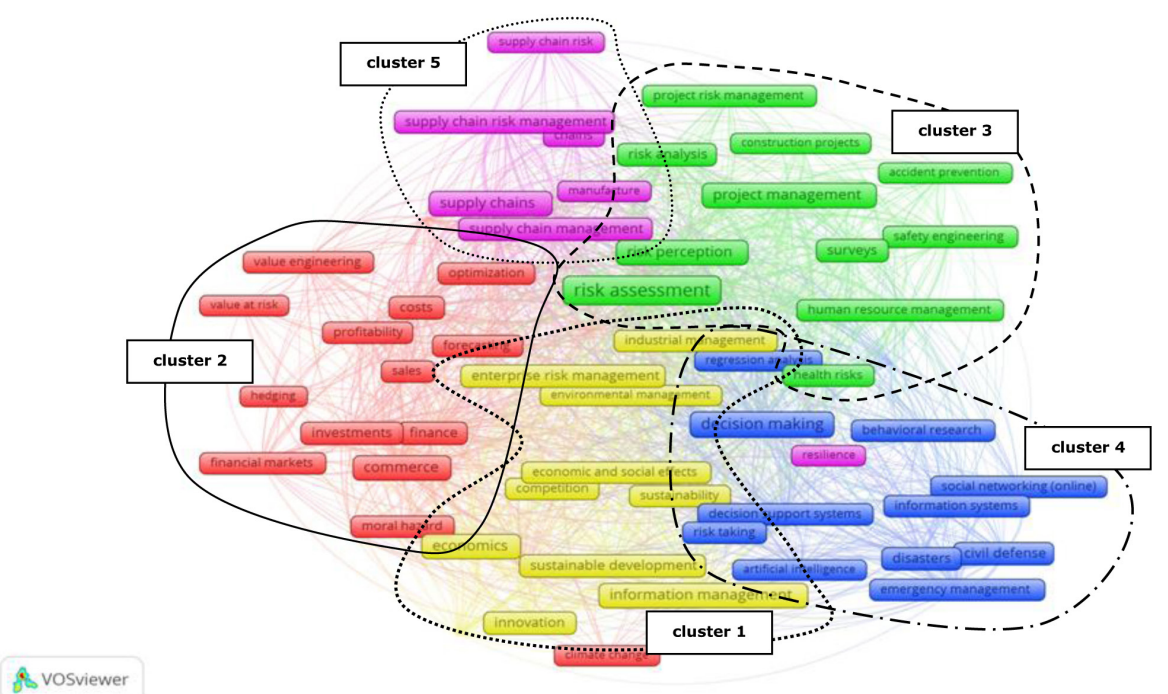

Figure 9: Map of research trends in publications referring to risk management in the period 2015-2017 (based on co-occurrence of the keywords). Source: own processing via VOSviewer program, data extracted from Scopus database. 


\section{Limitations of the Study}

While this study contributes to both literature, some limitations open up avenues for further research. First, risk management is undoubtedly a multidimensional concept (not only in management science), and in this study, are investigated only leading trends in this area. There are many other areas of challenges in risk management and future research should investigate the relationships between other dimensions of this concept. Second, this research aimed to identify selected challenges only over past 20 years in an exploratory way. Future research could extend this research concept here identified complementing it with dedicated areas such as business aspects. Finally, based on this study, future research could use these findings in management practice.

\section{Conclusion}

By summarizing, it seems apparent from the review of knowledge maps in the increasing research literature and growing body of knowledge within risk management, that research on the impact of risk management is a multidisciplinary research area. Based on the method of network analysis, which has been used to review a change of risk management concepts over last 20 years, it can be concluded that this concept is still strongly developed.

This area undoubtedly constitutes still great challenges to modern entities. The complexity and multidimensionality of the variables that determine contemporary decision-making processes require the decision-makers to take a look at the role of risk management in company processes from different perspectives (i.e. "soft" behaviours). In the author's opinion, the results of research presented in this study may provide a basis for further work in this area.

\section{Acknowledgments}

The author would like to thank the anonymous reviewers for their valuable comments and suggestions to improve the quality of the article.

\section{References}

Armstrong, C. S., Vashishtha, R. (2012). Executive stock options, differential risk-taking incentives, and firm value. Journal of Financial Economics, 104 (1), 70-88.

Bernstein P. L. (1997). Against the Gods: The remarkable story of risk [Przeciw bogom. Niezwykłe dzieje ryzyka]. Warszawa: WIG Press.

Bertinetti, G. S., Cavezzali, E., Gardenal, G. (2013). The effect of the enterprise risk management implementation on the firm value of European companies. Working Paper. Department of Management, Università Ca'Foscari Venezia, 10.

Christiansen, U. (2013). The management object in risk management approaches: How risk management frames the possible actions for managing risks, Working Paper Copenhagen Business School. Retrieved from: http://openarchive.cbs.dk/bitstream/handle/10398/8743/Ulrik_Christiansen. pdf? sequence=1.

Dabi, Y., Darrigues, L., Katsahian S., Azoulay, D., De Antonio, M, Lazzati, A. (2016). Publication trends in bariatric surgery: A bibliometric study. Obesity Surgery, 26 (11), 2691-2699.

Faccio, M., Marchica, M. T., Mura, R. (2016). CEO gender, corporate risk-taking, and the efficiency of capital allocation. Journal of Corporate Finance, 39, 193-209.

Gorzeń-Mitka, I. (2010). Evolution of corporate risk management approach. In. S. Hittmar (Ed.), Knowledge base for management - theory and practice (pp.84-89), Zilina: EDIS - Publishing House of the University of Zilina.

Gorzeń-Mitka, I. (2016). Leading risk management determinants of small and medium-sized enterprises (SMEs): An exploratory study in Poland. Eurasian Studies in Business and Economics, 3 (1), 289-298.

Gorzeń-Mitka, I. (2017). Bricolage concept in risk culture assessment. European Journal of Sustainable Development, 6 (1), 335-343. 
Iwona GORZEŃ-MITKA. The evolution of risk management research: Changes in knowledge maps

PROBLEMS

OF MANAGEMENT

IN THE $21^{\text {st }}$ CENTURY Vol. 12, No. 2, 2017

118

Gorzeń-Mitka, I. (2007). Ryzyko w eksporcie. Metody i sposoby ograniczania [Risk in export. Methods and ways of limiting]. Warszawa: KeyText.

Gudanowska, A. E. (2017). A map of current research trends within technology management in the light of selected literature. Management and Production Engineering Review, 8 (1), 78-88. DOI: 10.1515/mper-2017-0009.

Haviernikova, K. (2016). The identification and classification of risks in terms of cluster cooperation. In. M. Okręglicka, I. Gorzeń-Mitka, A. Lemańska-Majdzik, M. Sipa, A. Skibiński (Eds.), Proceedings of 1st international conference contemporary issues in theory and practice of management (130136), Czestochowa: Czestochowa University of Technology.

Hopkin, P. (2010). Fundamentals of risk management: Understanding, evaluating and implementing effective risk management. London, England; Philadelphia, Pennsylvania; New Delhi, India: Kogan Page.

Kahneman, D., Tversky, A. (1979). Prospect theory: An analysis of decision under risk, Econometrica, XLVII, 263-291.

Khalil, G. M., Gotway Crawford, C. A. (2015). A bibliometric analysis of U.S. based research on the behavioral risk factor surveillance system. American Journal of Preventive Medicine, 48 (1), 5057.

Kim, Y., Vonortas, N. S. (2014). Managing risk in the formative years: Evidence from young enterprises in Europe. Technovation, 34 (8), 454-465.

Kraus, V., Lehner, O. M. (2012). The nexus of enterprise risk management and value creation: A systematic literature review. ACRN Journal of Finance and Risk Perspectives, 1 (1), 91-163.

Kuběnka, M., Slavíček, O. (2016). Relationship between level of prosperity and failure prediction. SGEM 2016: Political Sciences, Law, Finance, Economics and Tourism Conference Proceedings (Book 2, vol. 3, pp. 505-512). Sofie: STEF 92 Technology Ltd.

Labarge, S., (2003). Valuing the risk management function. The RMA Journal, 85 (9). Retrieved from: http://www.questia.com/read/1G1-103088927/valuing-the-risk-management-functionrma-s-2003.

Liebenberg, A. P., Hoyt, R. E. (2003). Determinants of enterprise risk management: Evidence from the appointment of chief risk officers. Risk Management and Insurance Review, 6, 37-52.

Mesjasz-Lech, A. (2012). Efektywność ekonomiczna i sprawność ekologiczna logistyki zwrotnej [Economic efficiency and ecological efficiency of reverse logistics]. Częstochowa: Wydawnictwo Politechniki Częstochowskiej.

Mikes, A., Kaplan, R. S. (2013). Towards a contingency theory of enterprise risk management. Harvard Business School, Working Paper, 13-063 (1).

Modigliani, F., Miller, M. H. (1958). The cost of capital, corporation finance and the theory of investment. American Economic Review, 48, 261-297.

Olszewska, A. M. (2017). Research issues undertaken within quality management - overview of selected literature and a knowledge map. Procedia Engineering, 182.

Paligorova, T. (2010). Corporate risk taking and ownership structure. Bank of Canada Working Paper, 3.

Seamer, M., Choi, B. B., Doowon, L. (2012). Determinants of the rigour of enterprise risk management strategies: Evidence from Australia. Retrieved from: https:// web.actuaries.ie/sites/default/files/erm-resources/91_determinants_rigour_ ERM.pdf.

Sipa, M. (2017). Innovation as a key factors of small business competition. European Journal of Sustainable Development, 6 (1), 344-356.

Sipa, M., Skibnski, A., Gorzeń-Mitka, I. (2016). Intergenerational cooperation in the organization - view from a gender perspective. In. M. Okręglicka, I. Gorzeń-Mitka, A. Lemańska-Majdzik, M. Sipa, A. Skibiński (Eds.), Proceedings of 1st international conference contemporary issues in theory and practice of management (384-389), Czestochowa: Czestochowa University of Technology.

Skibiński, A. (2017). The changes of the population structure and its consequences in selected EU countries - some aspects. European Journal of Sustainable Development, 6 (1), 357-368.

van Eck, N. J., Waltman, L. (2016). VOSviewer manual. Manual for VOSviewer version 1.6.5, software documentation. Leiden: Univeristeit Leiden, 1(1). Retrieved from: www.vosviewer.com/ download/f-y2s2.pdf.

Verbano, Ch., Venturini, K. (2013). Managing risks in SMEs: A literature review and research agenda. Journal of Technology, Management and Innovation, 8 (3), 186-197.

Wieczorek-Kosmala, M. (2017). Kapitat ryzyka w przedsiębiorstwie [Risk capital in the enterprise]. Warszawa: CEDEWU.

Ziegler, B. E. (2009). Methods for bibliometric analysis of research: Renewable energy case study (Doctoral dissertation, Massachusetts Institute of Technology). Retrieved from: http://web.mit. edu/smadnick/www/wp/2009-10.pdf. 


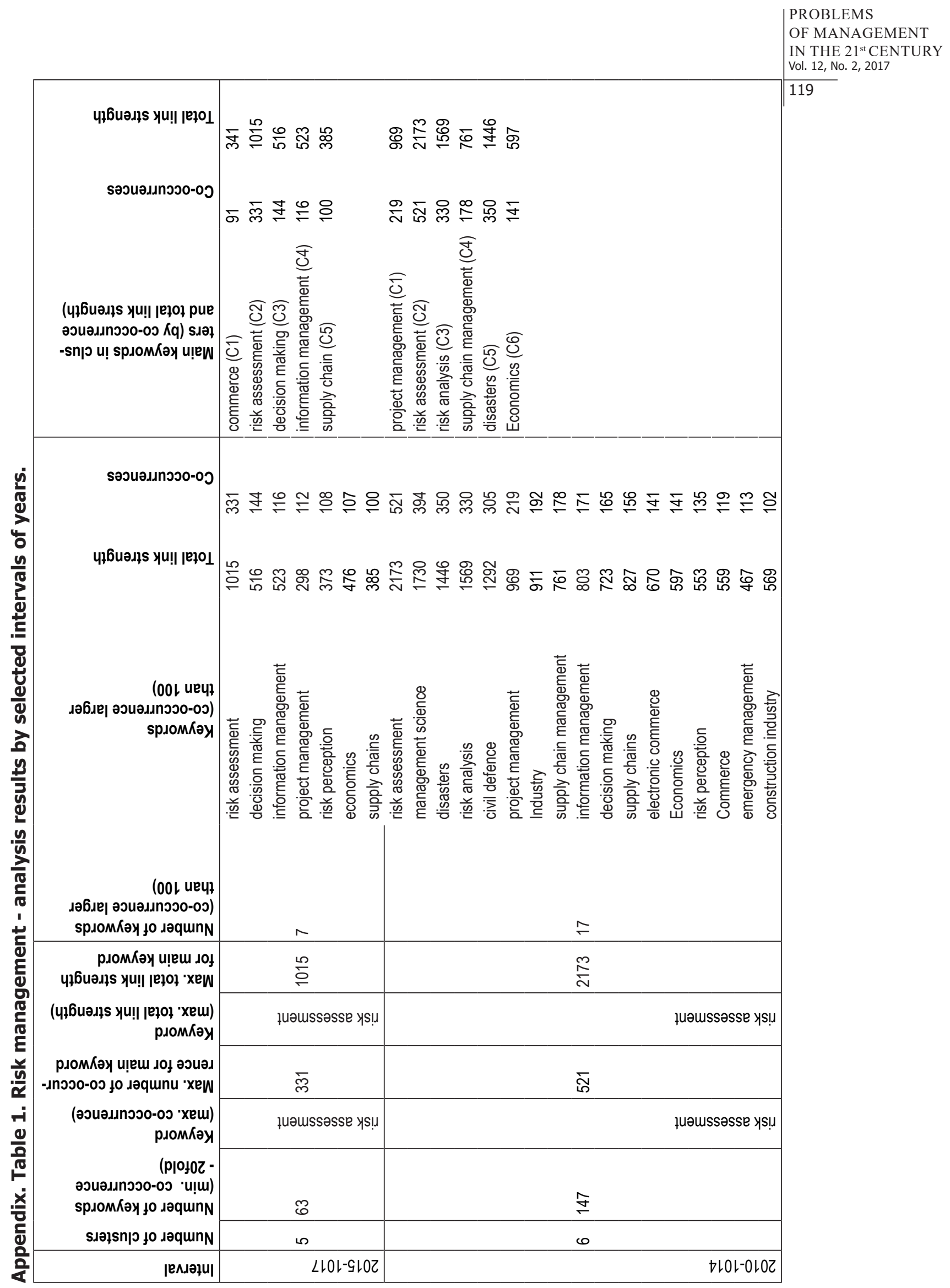


Iwona GORZEŃ-MITKA. The evolution of risk management research: Changes in knowledge maps

PROBLEMS

OF MANAGEMENT

IN THE $21^{\text {st }}$ CENTURY

Vol. 12, No. 2, 2017

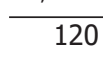

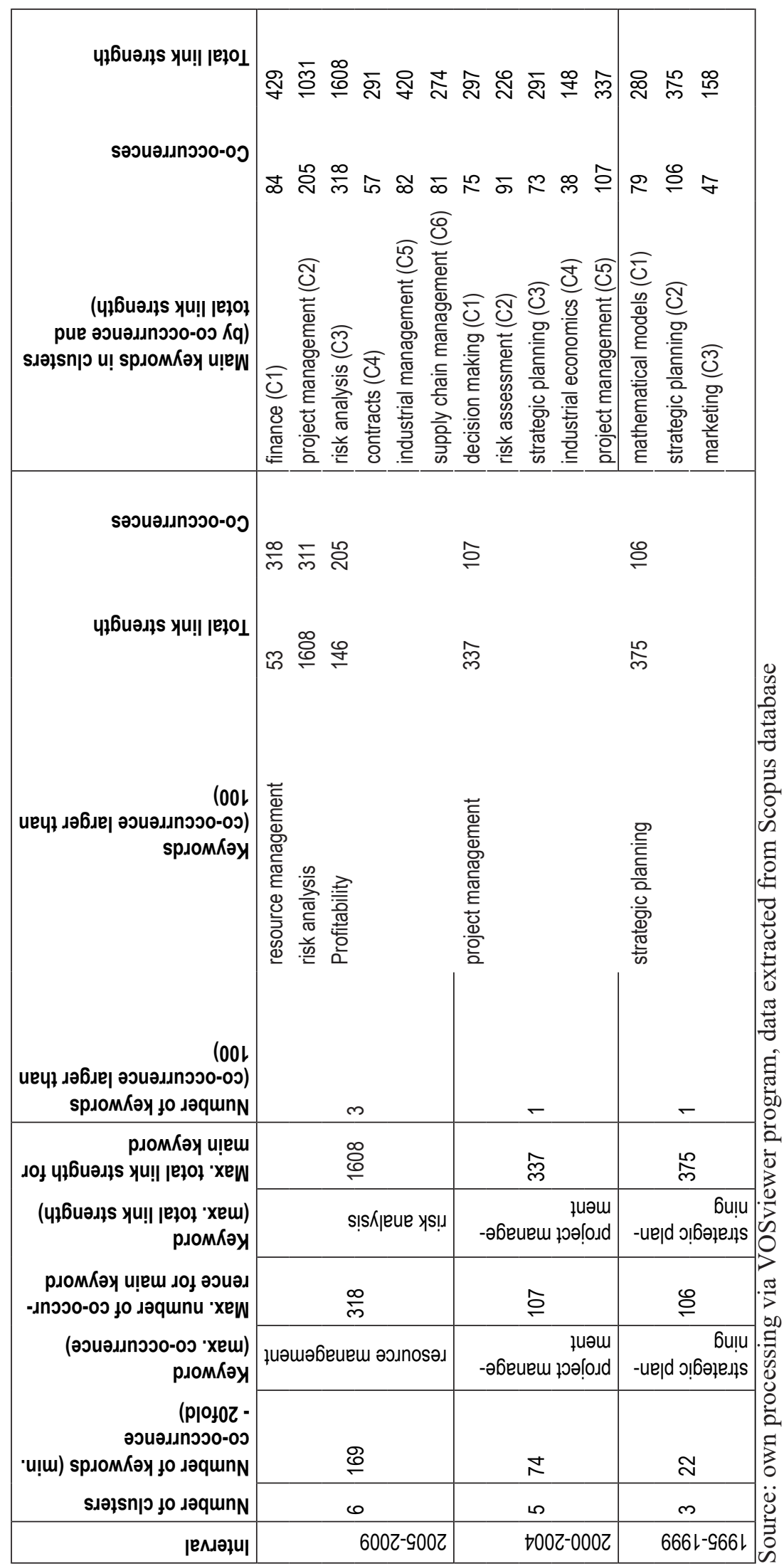


Iwona GORZEŃ-MITKA. The evolution of risk management research: Changes in knowledge maps

PROBLEMS

OF MANAGEMENT

IN THE $21^{\text {st }}$ CENTURY

Vol. 12, No. 2, 2017

Received: October 08, 2017

Accepted: December 12, 2017

121

Iwona Gorzeń-Mitka

PhD., Assistant Professor, Faculty of Management, Czestochowa University of Technology, Al. Armii Krajowej 19B, 42-201 Czestochowa, Poland.

Email: iwona.mitka@zim.pcz.pl

Website: http://www.zim.pcz.pl/profile/295,iwona-gorzen-mitka 